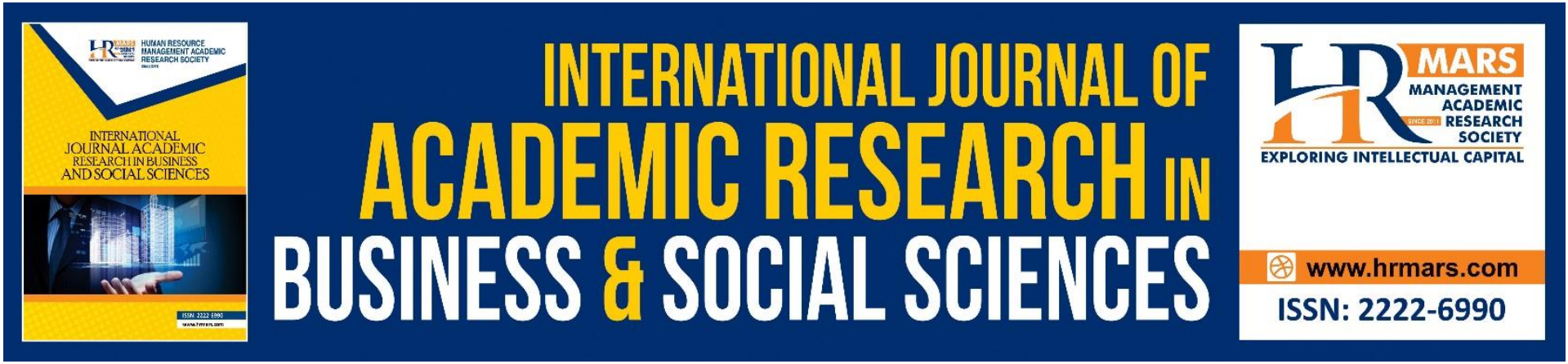

\title{
TVET Students' Attitudes and Motivation toward Learning English
}

Mohamad Fazil Mohd Zin, Melor Md. Yunus

To Link this Article: http://dx.doi.org/10.6007/IJARBSS/v10-i11/8134

DOI:10.6007/IJARBSS/v10-i11/8134

Received: 08 September 2020, Revised: 30 September 2020, Accepted: 19 November 2020

Published Online: 26 November 2020

In-Text Citation: (Zin, \& Yunus, 2020)

To Cite this Article: Zin, M. F. M., \& Yunus, M. M. (2020). TVET Students' Attitudes and Motivation toward Learning English. International Journal of Academic Research in Business and Social Sciences. 10(11), 717727.

Copyright: (c) 2020 The Author(s)

Published by Human Resource Management Academic Research Society (www.hrmars.com) This article is published under the Creative Commons Attribution (CC BY 4.0) license. Anyone may reproduce, distribute, translate and create derivative works of this article (for both commercial and non-commercial purposes), subject to full attribution to the original publication and authors. The full terms of this license may be seen at: http://creativecommons.org/licences/by/4.0/legalcode

Vol. 10, No. 11, 2020, Pg. 717 - 727

Full Terms \& Conditions of access and use can be found at http://hrmars.com/index.php/pages/detail/publication-ethics 


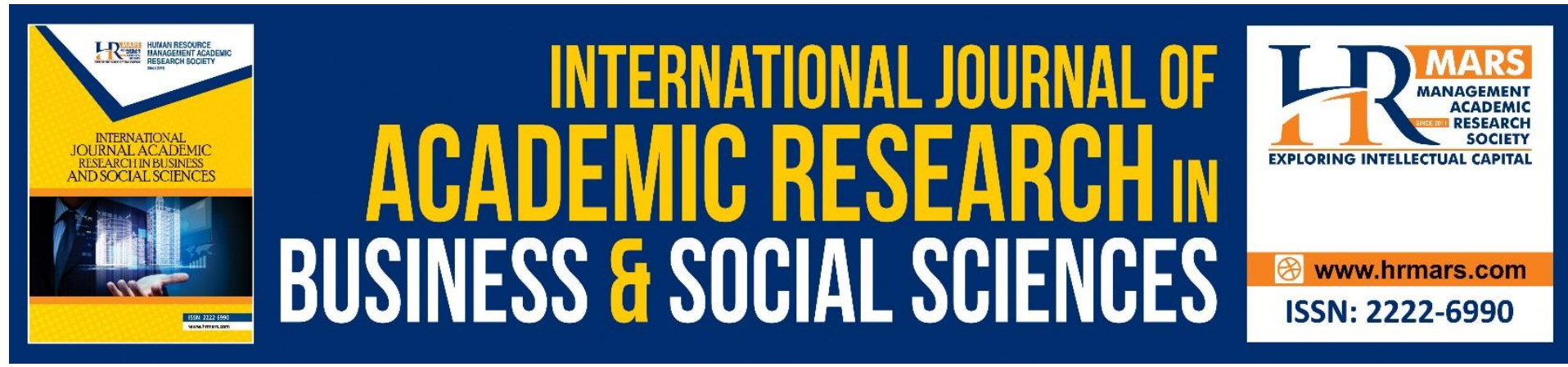

\title{
TVET Students' Attitudes and Motivation toward Learning English
}

\author{
Mohamad Fazil Mohd Zin, Melor Md. Yunus \\ Faculty of Education, Universiti Kebangsaan Malaysia
}

\begin{abstract}
The English language plays a vital appearance worldwide, especially in educational institutions, regardless of any levels. Besides, many educational institutions have implemented the English language as an influential feature of interaction for teachers and students, mainly teaching and learning. Thus, this study is to examine students' attitudes and motivation in English language learning. The research design employed in this study is a survey and instrument adapted from Gardner's (1985), the Attitude and Motivation Test Battery (AMTB). The questionnaire distributed to 37 male and 23 female students. According to the findings, students with a positive attitude possess a high motivation to be conversant in English. Perhaps students with positive attitudes and high motivation could enact Band 3 in the Malaysian University English Test (MUET) and above.
\end{abstract}

Keywords: Attitudes, Education, English Language, Motivation, TVET

\section{Introduction}

Back in the history lane, TVET was established in Malaysia in 1964 under the Technical Management Department, presently known as the Technical and Vocational Education Division. The primary goal of TVET is to develop students for world industrial settings and boost the government's initiatives to improve the industrial economy policy. With the growing count of skilled workers and enhancing the technology needed in the manufacturing and industrial divisions, the Ministry of Education, Malaysia (MOE), took many actions in 1995 by implementing the Technical Manpower Improvement Action Plan. Apart from focusing on practical assessments, students must learn English to reserve a spot in the industrial sector (Yaakob, Awang, Ismail, Zain, Kasim, Adnan, 2020).

The English language has become a universal language that has been employed by many people around the world, specifically in education. According to (Yunus, Sukri, 2017), the significance of comprehending the English language resulting from developing competitiveness academically in the world-class arena and prepare students to meet any shortcomings in the future (Yunus, Hern, 2011). In Malaysia, after the Malay language, English became a second official language after the British's former province left the country (Thirusanku, Yunus, 2012). Since the preschool, students have been subjected to the English language as well as in the tertiary level. There are public universities such as Universiti Sains Malaysia (USM), Universiti Tun Hussein Onn (UTHM), Universiti Sains Islam Malaysia (USIM), 
and Universiti Malaysia Pahang (UMP) that set the least Band 3 for students in the Malaysian University English Test (MUET).

However, some students who received Band 3 has not yet surpassed 50\% since 2012 (Majlis Peperiksaan Malaysia, 2019). Therefore, with the establishment of introductory classes to further assist students with Band 1 and 2 to obtain excellent achievement, the least is Band 3. Scores are somehow unsatisfying because some students demonstrate unpleasant attitudes, like being playful with the language and do not pay attention in the classroom, proving that they have less encouragement to study English (Normazidah, Koo, Hazita, 2012) and excel in their MUET (Othman, Nordin, 2013).

Several studies have been accomplished to measure student attitudes and motivation to learn English (Ryan, Deci, 2000; Wijnia, Loyens, Derous, 2010; Kocakoglu, Turkmen, Solak, 2010). Attitude is the essential key which can arouse students in studying languages. According to Jee \& Byun (2020), students with a positive attitude in the English class will frequently participate in classroom activities. Also, Baaqeel (2020) asserts that students who exhibit decisive responses to learning the English language have an easier time acquiring the language and participating more in teaching and learning activities. Besides attitude, motivation is among the main factors in learning languages (Liang, Kelsen, 2018). Also, students' motivation in acknowledging English needs to be investigated since it influences to completion of any activities (Hall, 2011). Teachers are advised to spot students' motivation and attitude by organizing relevant activities and methodologies. With proper activities and approaches, students can indeed maximize their competencies and involvement in language learning. Also, Abdul Kadir, Abdullah, Thulasi Palpanadan, Zainal Abidin, Muhammad, Mohamed (2020) assert that students with a positive attitude can motivate to learn the language well. Therefore, this study intends to inspect:

- TVET students' attitudes in studying English

- TVET students' motivation in studying English

\section{Literature Review}

\section{Theory of Language Learning Motivation}

This study's theory is the language learning theory put forward by psychologists Howard Gardner and Wallace Lambert. As citing to Gardner (1985), motivation mainly entails three elements: motivational strength, interest and behaviours in grasping the language. Also, Gardner, Lysynchuk (1990) state several factors, such as anxiety, self-confidence, risk-taking, and others, depending on motivation. Gardner also noted that language learning strategies are unlikely to be used if a person is demotivated to learn the language. This theory emphasized that motivation is described as a combination of endeavour and willingness to accomplish the language learning objective and positive attitude toward learning the language.

\section{Attitudes}

Students with positive attitudes could improvise their understanding of learning a language and could be an impactful aspect of learning a foreign language, for instance, in learning English (Zulkefly, Razali, 2019). Students' attitude toward learning English is among the significant elements that been extensively discussed. Following Che Mat, Yunus (2014), an attitude could provide a straightforward outcome of students' accomplishments in the second language acquisition. Besides, Smith (1971), students' attitudes make things uncomplicated or much robust in a language setting. Csızér, Dörnyei (2005) also deem 
attitude is a compelling element in learning a target language. Nunan (2000) affirms learners' attitudes, competencies, and methods to determine whether they can grasp the language's complex component. Additionally, Açıkgöz (1992) claims that students' positive attitude is capable of maximizing their favorable outcome toward acquiring the language, and Gardner (1985) stresses attitude as a motivating aspect.

Three categories of attitudes were identified during language learning: Attitudes toward society and people who use the language, and attitudes toward the language learning (Stern, 1983). According to Wong, Dubey-Jhaveri Aditi (2015), learners with positive attitudes toward a target language learning conversing in it confidently regardless of time and place. Also, Tahaineh (2013), Jordanian undergraduate study was conducted, and findings displayed strongly positive responses towards the English language. Al-Quyadi (2000) also mentioned that his study students present positive responses to English's subject and continuous utilization of this language in their study and a part of a conversation in daily life.

Following Nathalie (2016), the most prominent finding stated that students showed a positive attitude toward learning English. They feel the English language is more advantageous than their mother tongue being used globally. Also, most of the students gave a vast number of good responses toward the English language, whereas they could express their feelings better when using English. Furthermore, a considerable number of students disagreed with the usage of the mother tongue language in the English subject class by teachers. In addition to a study by Zulkefly, Razali (2019), students with a positive attitude toward the second language learning would maximize their efforts to understand the language conversed by extracting the meaning. Also, Bobkina, Jelena \& Calyea, Miriam (2012), most students would not speak their mother tongue when in an English-speaking country. Another finding from a similar study demonstrated that a massive number of students disagreed the effort to acquire the English language came from luck or intelligence alone. At the same time, finding also revealed that most students disagreed with their teachers to converse in the mother tongue language when it comes to English class.

Furthermore, Gardner, Lysynchuk (1990) examined the purpose of attitudes in acquiring a second language. There were assorted findings analyzed after the process. Firstly, the finding found out that students who presented positive attitudes directly resulting in high motivation that improvise their efficiency in the target language. Secondly, the finding also managed to prove that students with positive attitudes toward the target language could assist the students in attaining excellent efficiency in the target language. Also, other forms of attitudes, either positive or negative, the way the learners depend on the target language, could affect their number of participation and engagement of learning a target language.

\section{Motivation}

Motivation is classified as the learners' purpose of action toward learning (Al-Tamimi, Shuib, 2009). Generally, motivation is categorized into two categories: intrinsic and extrinsic motivation. Intrinsic motivation develops naturally from within (Asmari, Javid, 2011). As following Dhaif-Allah, Al-Jumah (2020), intrinsically motivated students often have an interest in learning. Intrinsically motivated students are usually successful in learning because they can see the responsibilities of learning rather than rewards (Al-Dosari, 2014). Al-Harthy (2017) claims that learners become intrinsically motivated toward learning a foreign language when they are attentive to learning targets and the significance of learning it to future undertakings. Besides, Loganathan, Khan \& Zafar (2016) state that learners' willingness to learn a foreign language can boost intrinsic motivation. 
Fundamentally, students who are extrinsically motivated to keep learning for rewards and any real opportunities such as things, careers, and many more (Dhaif-Allah, 2005). Also, AlMahrooqi, Denman (2014) claim that a considerable number of learning activities are related to intrinsic and extrinsic motivation. Commonly, students become more enthusiastic and pay close attention to learning a foreign language because it is a new language after their mother tongue. Since it is a new language, they are so eager to learn and explore more toward learning it. At the same time, a foreign language has become compulsory in most educational institutions for students to pass, and they study hard to excel in the examination prepared according to the requirements. Al-Dosari (2014) asserts that rewards that learners perceive could control their attitude and eventually decrease intrinsic motivation. As they are wellequipped with knowledge and positivity, they well aware of the importance of proficiency and adequacy of conversing in it, therefore upsurge intrinsic motivation.

Based on a previous study by Bobkina, Jelena \& Calyea, Miriam (2012), the majority of the findings were positive whereas $80.5 \%$ of respondents gave positive responses toward good English command from teachers makes them more competitive in learning the English language, while $87.4 \%$ of students affirmed, learning English is vital so they can live in the English-speaking country. The overall findings proposed that most students gave positive responses to the motivation statements and proven that respondents have high motivation to learn English.

Following Nathalie (2016), the previous study on motivation and attitude toward learning the English language, a massive number of students feel motivated to understand what they hear and see as it involves the English context. Also, a vast number of students were motivated to ask help from their teachers when they face difficulty in English class. Besides, most students realized the usefulness of learning the English language as it has become a universal language that could be beneficial for their future. The findings concluded most students were motivated to learn the English language for future endeavors.

According to Gardner (1985), students' positive attitudes and high motivation appear to do well than students with negative attitudes and less motivation. Furthermore, to have a successful language learning experience, these two elements are mandatory to develop together. Gardner (1979) also points out that students' attitude to language learning is pleasing, but not motivated; he/she will not succeed as language learners. Ellis (1997) supports this interrelationship between attitude and motivation toward language learning. Researchers Samsiah Bidin, Kamaruzaman Jusoff, Nurazila Abdul Aziz, Musdiana Mohammad Salleh, Taniza Tajudin (2009) and Thang (2011) further underline this effective interconnection, proposing that students with positive attitudes and high motivation tend to become outstanding and competitive. In line with a study from Weng, Yunus, Embi (2016), teachers and students are also playing a vital role in conjunction to present a productive learning environment that could increase students' motivation in learning.

Motivation keeps people working, performing tasks, and achieving goals in their lives. Moreover, motivation is closely related to the learners' options that involve targets of doing it, impactful activities, proper preparation before starting the learning process, making a decision, and the way out of a problem (Schunk, Pintrich, Meece, 2008). Motivated students have their favorite options to decide on; they should learn techniques to improve their learning process and make all their plans work. 


\section{Methodology}

The approach employed in this study was a survey research design, conducted at two vocational colleges in Johor and Selangor. In this study, the participants incorporated 37 male and 23 female students of Diploma in Creative Multimedia and Animation from vocational colleges in Johor and Selangor. In total, 60 volunteered participants involved in the study. Besides, the researcher adopted an instrument from Gardner's (1985), the Attitude and Motivation Test Battery (AMTB) to look at students' attitudes and motivation in learning the English language. Next, an instrument consists of three parts. Firstly, demographic information. Secondly, regarding motivation and lastly about attitude. Also, an instrument employed a four-point Likert-scale ranging from Strongly Disagree (1), Disagree (2), Agree (3), and Strongly Agree (4), and the data were analyzed in descriptive statistics.

\section{Findings and Discussion \\ Demogprahic Information}

Demographic information is the details of the respondents, such as gender involved in this study. The overall count of respondents involved in this study were 60 respondents. The breakthrough, according to genders were 37 male and 23 female students, while 26 students came from one of the vocational colleges in Johor, and 34 students came from one of the vocational colleges in Selangor.

\section{Attitudes}

An instrument adapted from Gardner's (1985), the Attitude and Motivation Test Battery (AMTB) to look at students' attitudes toward learning English. There are seven items on attitudes in total. The data analyzed has been ranked from highest to the lowest mean.

Table 1 - Descriptive Statistics on Students' toward learning English

Mean Deviation

Items

(M)

(SD)

1) If I were on trip in an English-speaking country, I would attempt to communicate English.

$3.80 \quad 0.480$

2) When I listen to an English song on the radio or watch a movie, I attempt to comprehend the meaning.

$3.76 \quad 0.499$

3) If I did not have the opportunity to learn English at the university, I would practice it momentarily.

$3.48 \quad 0.700$

4) In the language classroom, I like to communicate as much English as possible.

5) I am keener to learn some other different languages besides English.

2.610 .903

6) I tend to favour our English teacher to clarify things in a primary language.

7) I genuinely think of fortune or intellectual ability to the extent that I do not make too much effort to learn English.

\section{$2.23 \quad 0.945$}

$\mathrm{n}=60$

Based on the data collected that has been ranked in the questionnaire (Table 1, Item 1), the highest $M=3.80, S D=0.48$, resulted that most respondents would try to speak English during a holiday at an English-speaking country. Next, with $\mathrm{M}=3.76, \mathrm{SD}=0.49$, most respondents would attempt to comprehend when listening to an English song on the radio or watching a 
movie (Table 1, Item 2). In line with a study from Wong, Dubey-Jhaveri Aditi (2015), learners with positive attitudes toward second language learning tend to converse in it confidently regardless of time and place. Also supported by Zulkefly, Razali (2019), students with a positive attitude toward the second language learning would maximize their efforts to understand the language conversed by extracting the meaning. Besides that, Bobkina, Jelena \& Calyea, Miriam (2012), the majority of the students would not speak their mother tongue when in an English-speaking country.

However, the lowest $M=2.23, S D=0.94$, proven that some respondents believe in luck or intelligence yet do not need to put too much effort to learn English (Table 1, Item 7) and followed by $M=2.33, S D=1.08$, showed that only several respondents prefer the English teacher to explain things in mother language (Table 1, Item 6). As supported by Bobkina, Jelena \& Calyea, Miriam (2012), the majority of the students would not speak their mother tongue when in an English-speaking country. Another finding from the same study also demonstrated that a massive number of the students disagreed the effort to acquire the English language came from luck or intelligence alone. At the same time, finding also revealed that most students disagreed with their teachers to converse in mother tongue language when it comes to English class. Furthermore, Nathalie (2016) purported a considerable number of students disagreed with the usage of mother tongue language in the English subject class by teachers.

\section{Motivation}

An instrument adapted from Gardner's (1985), the Attitude and Motivation Test Battery (AMTB) to look at students' motivation towards learning English. There are twelve items on motivation in total. The data analyzed has been ranked from highest to the lowest mean.

Table 2 - Descriptive Statistics on Students' Motivation toward learning English

\begin{tabular}{lcc}
\hline & MeanStd. Deviation \\
I learn English because... & (M) & (SD) \\
\hline 1) I need it for future endeavors in my career. & 3.81 & 0.390 \\
2) I need it for my studies. & 3.65 & 0.605 \\
3) It is convenient to stay connected with the English speaker. 3.65 & 0.659 \\
4) I prefer to discover new things. & 3.63 & 0.688 \\
5) It is what I need to make the journey to foreign countries. & 3.60 & 0.693 \\
6) It enables me to receive an excellently-paid job. & 3.51 & 0.650 \\
7) I require it to receive financial aid. & 3.48 & 0.724 \\
8) It encourages me to take part in cultural events. & 3.46 & 0.650 \\
9) Learning is a gratifying process. & 3.46 & 0.700 \\
10) I keen to learn foreign languages. & 3.45 & 0.648 \\
11) It serves to make me more competitive. & 3.45 & 0.768 \\
12) I admire to live in a nation that speaks English. & 2.91 & 1.046 \\
\hline n=60 & &
\end{tabular}

Based on the data tabulated that has been ranked in the questionnaire (Table 2, Item 1), the highest $M=3.81, S D=0.39$, showed that most respondents need to learn English for a professional career. Next, with $M=3.65, S D=0.60$ resulted that most respondents need to learn English for studies (Table 2, Item 2). As supported by a study by Dhaif-Allah, Al-Jumah (2020), intrinsically motivated students often have an interest in learning. Intrinsically 
motivated students are usually successful in learning because they can see the responsibilities of learning rather than rewards (Al-Dosari, 2014).

However, with the lowest $M=2.91, S D=1.04$, a few respondents chose to learn English as to live in English-speaking country (Table 2, Item 12 ) and only several respondents with $M=3.45$, $\mathrm{SD}=0.76$ chose to learn English as to be a more competitive person (Table 2, Item 11). As supported by Al-Harthy (2017) claims that learners become intrinsically motivated toward learning a foreign language when learners aware of the learning goals and the significance of learning it to future undertaking. Besides, Loganathan, Khan \& Zafar (2016) state that learners' willingness to learn a foreign language can boost intrinsic motivation. Moreover, based on a previous study by Bobkina, Jelena \& Calyea, Miriam (2012), most of the findings were positive, whereas $80.5 \%$ of the respondents gave positive responses toward proper English commands from teachers, making them more competitive in learning the English language. Besides, $87.4 \%$ of the students affirmed that it is vital to learn English so they can live in an English-speaking country.

\section{Conclusion}

Overall findings concluded that students provided a positive attitude and high motivation toward learning English. Therefore, this study managed to answer the purpose of the study. Hopefully, with the results earned, teachers would be able to generate more exciting and proper activities in conjunction to make a successful teaching and learning settings. Also, an additional study is indeed to be more specific to identify different aspects such as language anxiety and learning methods that suitable in their learning process. Finally, recognizing their attitudes and motivation could be an appropriate reference for teachers to generate motivating yet amusing activities in class, hence leading them to be more proficient in the language. Perhaps students with positive attitudes and high motivation could achieve at least Band 3 in MUET and above.

Moreover, this study's findings could also redound to society's benefits since English has remarkably become the global communication language in daily conversation. Practically, TVET students are trained to produce things based on the modules constructed. Hence, learning English it sets a potential move for TVET students to market their products not only in local settings but also globally. Also, to ensure their future buyers from different countries to have a better understanding of their products, the English language is the bridge that connects buyers and their products. Since English has been used globally, most references and modules are written in English. As a part of developing learning experience, students must associate with a variety of references and modules relating to their courses from all educational institutions around the world to generate more outstanding ideas in the future. Besides, teachers could also take part in adapting an ample of teaching approaches from any references around the world to set an exciting learning session. For instance, traditional teaching methods could remain its effectiveness, but with a presence of technology in it might improve teaching adaptability for teachers and students in the classroom. Therefore, the English language is not only restricted for daily conversation; it is yet vital to education.

\section{Acknowledgement}

This research was supported by the grants from the Faculty of Education, Universiti Kebangsaan Malaysia, GG-2020-014 and GG-2019-006. 


\section{References}

Acikgoz, U. K. (1992). Đşbirlikli öğrenme: Kuram, araştırma ve uygulama (Cooperative Learning, theory, research and evaluation). Malatya: Uğurel Matbaası.

Al-Dosari, H. (2014). The Entwined Effects of Attitude, Motivation, and Gender on EFL Learning: A Correlation Study. Studies in Literature and Language, 8(1), 1-5, https://dx.doi.org/10.3968/j.sll.1923156320140801.4183

Al-Harthy, S. (2017). English Language Motivation between Gender and Cultures. Journal of Educational and Social Research, 7(2), 123-132 https://dx.doi.org/10.5901/jesr. 2017.v7n2p123

Al-Mahrooqi, R., \& Denman, C. (2014). Motivation within the Omani EFL context: types, sources, and classroom implication. Journal of Teaching and Education, 3(2), 103120.

Al-Quyadi. (2000). Psycho-sociological variables in the learning of English in Yemen (Ph.D. Thesis, Bhagalpur University).

Al-Tamimi, A., \& Shuib, M. (2009). Motivation and attitudes towards learning English: A study of petroleum engineering undergraduates at Hadhramaut University of Sciences and Technology. GEMA Online Journal of Language Studies, 9(2), 29- 55.

Asmari, A. A., \& Javid, C. Z. (2011). Motivational constructs: A cross-sectional study of EFL students at Taif University. Journal of Social Sciences \& Humanities, XIX (2), 73-104.

Baaqeel, N. A. (2020). Improving Student Motivation and Attitudes in Learning English as a Second Language; Literature as Pleasurable Reading: Applying Garner's Theory of Multiple Intelligences and Krashen's Filter Hypothesis. Arab World English Journal for Translation \& Literary Studies4 (1)137-51. DOI: http://dx.doi.org/10.24093/awejtls/vol4no1.4

Bobkina, J., \& Calyea, M. (2012). Motivation and Attitudes towards Learning English: A Study of Engineering Undergraduates at the Technical University of Madrid.

Dhaif-Allah, A. (2005). An Exploration of Saudi Students' Integrative and Instrumental Motivation for Learning English as a Foreign Language. Occasional Papers, CDELT, Ain-Shams University, 38, 57-96.

Dhaif-Allah, A. S., \& Al-Jumah, F. H. (2020). Differences in Motivation for Learning English among Saudi University Students. English Language Teaching, 13(2), 63. DOI:10.5539/elt. v13n2p63 Ellis, R. (1997). Second language acquisition. Oxford: Oxford University Press.

Gardner, R. C., \& Lysynchuk, L. M. (1990). The role of aptitude, attitudes, motivation, and language use on second-language acquisition and retention.

Canadian Journal of Behavioral Science/Revue Canadienne des Sciences Du Comportment, 22(3), 254. DOI:10.1037/ h0078924

Gardner, R.C. (1979). Social psychological aspects of second language acquisition. In H. Giles \& St. Clair, R. (Eds). Language and social psychology, hlm. 193-220. Oxford: Basil Blackwell

Gardner, R. C. (1985). Social Psychology and Second Language Learning: The Role of Attitudes and Motivation. London: Edward Arnold.

Hall, G. (2011). Exploring English language teaching language in action. London: Routledge Academic Management Office, 2018.http://dx.doi.org/10.2307/329249.

Jee, M. J., \& Byun, J. (2020). Korean university EFL students' motivation, demotivation, and attitudes toward learning English. Journal of Linguistic Studies, 25(1), 95-112.

DOI:10.21291/jkals.2020.25.1.6 
Kocakoglu, M., Turkmen, L., \& Solak, K. (2010). Motivational styles in problem-based learning. Procedia Social and Behavioral Sciences, 2: 615-619.

Liang, H. Y., \& Kelsen, B. (2018). Influence of personality on oral presentation performance. Journal of PsycholinguisticResearch,47(4),755-776

Loganathan, S., Khan, Z., \& Zafar, S. (2016). Influence of Motivational Factors and Gender Differences on Learning English as a Second Language: A Case of Engineering Students from Rural Background. Indian Journal of Science and Technology, 9(44), 17.

Majlis Peperiksaan Malaysia. (2019).Retrieved from http://www.mpm.edu.my/on 24 August 2019.

Nathalie, A. A. (2016). Motivation and Attitude of Students towards Learning the English Language. International Conference on Research in Social Sciences, Humanities and Education (SSHE-2016) May 20-21, 2016 Cebu (Philippines). DOI:10.17758/uruae. uh0516002

Normazidah, C. M., Koo, Y. L., and Hazita, A. (2012). Exploring English language learning and teaching in Malaysia. GEMA Online ${ }^{\mathrm{TM}}$ Journal of Language Studies, 12(1), 35-55. Nunan, D. (2000). Language teaching methodology (2nd Impression ed.). Harlow: Pearson Education Ltd.

Othman, J., \& Nordin, A. B. (2013). MUET As A Predictor of Academic Achievement in ESL Teacher Education. GEMA Online ${ }^{\mathrm{TM}}$ Journal of Language Studies, 13(1), 99-111.

Ryan, R. M., \& Deci, E. L. (2000). Intrinsic and Extrinsic Motivations: Classic Definitions and New Directions. Contemporary Educational Psychology. 25: 54-67.

Schunk, D. H., Pintrich, P. R. \&Meece, J. (2008). Motivation in Education: Theory, Research, and Application. 3rdEd.USA: Allyn and Bacon.

Smith, A. (1971). The importance of attitude in foreign language learning. The Modern Language Journal, 55 (2), 82-88. Retrieved from https://www.jstor.org/ stable/pdf/321854.pdf

Stern, H. H. (1983). Fundamental concepts of language teaching. Oxford: Oxford University Press.

Thang, S. M. (2011) Attitudes and Motivation of Malaysian Secondary Students towards learning English as a Second Language: A Case Study. 3L: The Southeast Asian Journal of English Language Studies, 17(1): $40-54$

Thirusanku, J., \& Yunus, M. M. (2012). The many faces of Malaysian English.InternationalScholarlyResearchNetwork,2012.https://doi.org/10.5402/2012/ 138928Weng, P. L., Yunus, M. M., \& Embi, M. A. (2016). Successful Language Learning Strategies Used By Successful Year 5 English As A Second Language (Esl) Learners. Proceedings of the ICECRS, 1(1). DOI:10.21070/picecrs.v1i1.523

Wijnia, L., Loyens, S. M. M., \& Derous, E. (2010). Investigating the effects of problem-based versus lecture-based learning environments on student motivation. Contemporary Educational Psychology,36(2), 101-113.

Wong, \& Dubey-Jhaveri, Aditi. (2015). English Language Education in a Global World: Practices, Issues, and Challenges (Contribution 50\%). 10.13140/RG.2.1.4479.1129

Yaakob, M. F., Awang, H., Ismail, M. Z., Zain, F. M., Kasim, M., \& Adnan, A. A. (2020). Backward and Forward Reviews on Technical and Vocational Education and Training (TVET) in Malaysia: The Evolution and ICT-Driven Future Prospect. Universal Journal of educational research,8(6) 2197-2203.doi:10.13189/ujer.2020.080601 Yunus, M. M., \& Hern, G. E. (2011). Malaysian undergraduates' perceptions and 
attitudes on bilingual education. Procedia - Social and Behavioral Sciences, 15, 26182622. DOI:10.1016/j.sbspro.2011.04.157

Yunus, M. M., \& Sukri, S. I. (2017). The Use of English in Teaching Mathematics and Science: The PPSMI Policy vis-à-vis The DLP. Advances in Language and Literary Studies, 8(1), 133. DOI:10.7575/aiac.alls.v.8n.1p.133

Zulkefly, F., \& Razali, A. B. (2019). Malaysian Rural Secondary School Students' Attitudes towards Learning English as a Second Language. International Journal of Instruction, 12(1), 1141- 1156. https://doi.org/10.29333/iji.2019.12173a 